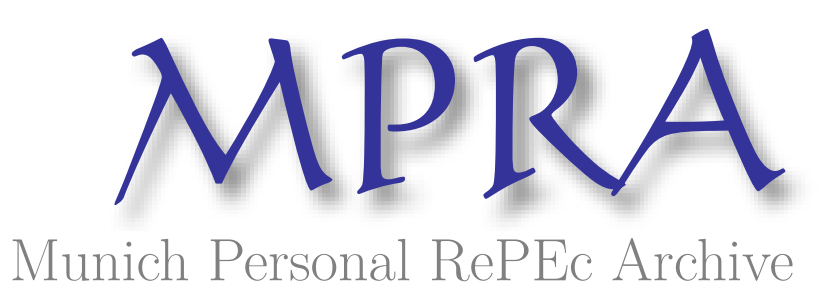

\title{
Danish Balance of Payments Support
}

Tarp, Finn

October 1995

Online at https://mpra.ub.uni-muenchen.de/62437/

MPRA Paper No. 62437, posted 02 Mar 2015 06:32 UTC 


\section{DISCUSSION PAPERS}

\section{5-16}

Danish Balance of Payments Support

Finn Tarp and Mads Váczy Kragh

Institute of Economics, University of Copenhagen Studiestræde 6, DK-1455 Copenhagen K, Denmark tel. +45 35322626 - fax. +453532 3000 



\title{
DANISH BALANCE OF PAYMENTS SUPPORT ${ }^{1}$
}

\author{
by
}

\author{
Finn Tarp and Mads Váczy Kragh \\ Institute of Economics \\ University of Copenhagen \\ Studiestraede 6 \\ DK-1455 Copenhagen K \\ Denmark
}

October 1995

\begin{abstract}
This study is an analysis of Danish Balance of Payments Support (BOP) covering the period 1988-94. This aid instrument has not so far been used as an active tool to further Danish policy conditionalities vis-à-vis the reform process in developing countries. On the contrary, BOP has mainly been used in a residual manner, and Commodity Import Support (CIS) has by far been the dominant modality used. Yet, fundamental changes are underway in parallel with the almost complete disappearance of the demand for traditional Danish import support commodities. Thus, other BOP instruments such as debt relief, credit lines, support to Open General License (OGL) systems and co-financing with the World Bank have been on the rise in recent years. Nonetheless, despite the macroeconomic nature of BOP assistance existing evaluation studies and reviews have focused on microeconomic and administrative issues related to BOP disbursements and proper programme management. Very little can therefore at this stage be concluded about the macroeconomic impact of Danish BOP aid.
\end{abstract}

Keywords: Adjustment, balance of payments support, evaluation of aid and international cooperation.

\footnotetext{
${ }^{1}$ This study was presented at an international workshop on 'The Evaluation of Balance of Payments Support' held at the Institute of Social Studies (ISS), The Hague on 12-13 October 1995. Kind assistance from various staff members of Danida is gratefully acknowledged. Particular thanks are due to Niels Dabelstein, Erik Schmidt-Hansen, Ole Mølgård Andersen, Ole Winckler Andersen and Ole Poul Hansen. Responsibility for any remaining errors and all views expressed rests solely with the authors.
} 


\section{Introduction}

This study was initiated at the request of the Institute of Social Studies (ISS), The Hague and forms parts of an international comparative analysis of the historical evolution of balance of payments support (BOP) and the methodologies adopted by aid donors in the evaluation of such assistance. The study covers the period 1988-94, and BOP is defined so as to include import support, debt relief as well as other forms of programme aid. More specifically, the following forms of general programme assistance as defined in the DAC 'Principles for Programme Assistance' (DAC, 1991) are included in addition to debt relief: balance of payments support, general budget support and commodity aid not related to specific projects. Hence, the remaining two categories of programme assistance (i.e., programme food aid and sector programme assistance) are not included.

Data on Danish BOP are with the exception of debt relief not compiled in summary form in Danida's annual reports or other similar published sources. Thus, to provide an overview of the composition and trends of disbursements of such aid, the detailed accounts of all ongoing BOP activities had to be reviewed. The relevant BOP projects were identified from the short descriptive outlines contained in the socalled project approval and completion reports prepared by the Research and Evaluation Unit (StS.4) of Danida. On the basis of this listing, the Finance Department for Development Assistance (StS.2) was in a position to supply the data, which could subsequently be transformed by the authors into the summary tables presented here. It is noted, however, that the information available does not allow a breakdown of the support to respectively Open General License (OGL) systems and credit lines, whereas commodity import support (CIS), debt relief and co-financing with the World Bank are in general identifiable categories.

Evaluation of Danish aid is the direct responsibility of StS.4, and on average 3\% of all Danish aid is evaluated by this unit with the assistance of external consultants. In addition to the evaluation studies, internal Danida reviews are carried out at various stages of project implementation involving the Technical Advisory Service (TSA), and also the Danish Court of Auditors produce studies, which are of direct relevance to the evaluation of Danish aid. However, due to the rather limited size of Danish BOP only one major evaluation study covering five countries (Tanzania, Mozambique, Uganda, Nicaragua and Bangladesh) has been carried out by Danida (see T\&B Consult, 1994). To this comes three minor reports from the late 1980s (CASA, 1989; Cooksey, 1987; and Danida, 1988) covering BOP activities in Tanzania and Mozambique. This study is based on these four analyses, but also the methodologies used in the internal reviews are commented upon below.

Section 2 provides a descriptive historical summary of Danish BOP with tables and figures indicating the importance of BOP in the overall aid programme. Breakdowns of the BOP assistance by main recipients and categories are also given, and the same accounts for the composition of the commodity import support programme. Subsequently, Section 3 identifies the main policy and other guidelines governing Danish BOP, and Section 4 reviews and characterizes existing BOP studies. Section 5 concludes and identifies the main lessons, which can be learnt. 


\section{Historical Evolution}

Although policy-based aid has been the subject of intense debate during the $1980 \mathrm{~s}$ and $1990 \mathrm{~s}$ in Denmark, this kind of aid has not so far played any significant role in Danish international development assistance in contrast to the situation for other like-minded donors such as Sweden, Norway and the Netherlands. Total Danish BOP given during 1988-94 amounted as can be seen from Table 1 to only DKK 2.2 billion corresponding to US $\$ 0.4$ billion. This is equivalent to approximately $8 \%$ of the bilateral and $4 \%$ of the total Danish aid budget for the whole period, and the trend has been on a pronounced decline from 1991 as shown in Figure 1. Moreover, only a very limited part of the BOP was explicitly linked to the implementation of policy conditionalities.

\section{[Table 1 and Figure 1 about here]}

With regard to the main recipients of Danish BOP, eight countries account as shown in Table 2 on average for $84 \%$ of the total BOP. This degree of concentration has, however, been falling significantly throughout the whole period from a level of $99 \%$ in 1988 to $68 \%$ in 1994 . All eight countries (i.e., Bangladesh, Tanzania, Uganda, Mozambique, Zimbabwe, Kenya and Nicaragua in order of decreasing importance) are socalled programme countries (i.e., major receivers of Danish bilateral aid). Yet, Bangladesh and Tanzania have by far been the most important receivers of Danish BOP. Nevertheless, by 1994 BOP to Bangladesh had come to an almost complete stand-still, and BOP to Tanzania had diminished to only $16 \%$ of the 1988 level in nominal terms. Also BOP to Nicaragua and Kenya had fallen to very low levels in 1994, whereas these drops were counteracted by increased BOP to Zimbabwe and Mozambique. Danish BOP to Zambia and Uganda has followed no obvious trend.

It can also be observed that Danish BOP has been concentrated on some of the poorest countries in the World, including in particular a relatively large number of countries in sub-Saharan Africa. This is in line with overall Danish aid priorities, where the extent and level of poverty is an important if not overriding criteria. It also follows that the number of receivers of Danish BOP increased from 1988 to 1995. This took place through the inclusion of countries such as Egypt, Cape Verde, Nepal, Mongolia, Burkina Faso, Madagascar, Kirgizstan, listed here in decreasing order of significance. Other countries, which have received BOP in the 1988-94 period, include Angola, Benin, Bolivia, Eritrea, Guyana and Honduras.

[Table 2 about here]

The major component of Danish BOP in 1988-94 has by far been commodity import support (CIS), which on average accounted for close to $71 \%$ of all BOP as shown in Table 3. This share has, however, dropped consistently from $95 \%$ in 1988 to only $38 \%$ in 1994 . Hence, while CIS in 1994 was still the largest component of Danish BOP, it was by no means the only modality used. One important characteristic of the CIS modality has been the possibility for rapid disbursement of unspent project funds at the end of the year in a residual manner to finance inputs to production activities. Yet, the CIS mechanism has at the same time made it possible for Danida to increase the share of the aid budgets received by Danish suppliers due to tying.

In fact, it would appear that the CIS modality has been used more with a view to the need for high 
disbursement and procurement in Denmark than being due to a perceived superiority of this-aid instrument with reference to the particular needs of receiving countries. This is underscored in a recent official report on programme assistance, which inter alia reports that prices for Danish CIS goods have in some cases been above world market prices (Danida, 1994, pp. 8-9). It is, moreover, confirmed that problems of proper planning and monitoring have in all likelihood been encountered as compared to present norms and regulations. These problems are not, however, specified in detail.

It can also be noted that the demand in receiving countries for the kinds of Danish goods, which have been used so far, has almost fallen away. Importers have less incentive to buy CIS goods tied to Danish suppliers such as fertilizers or cement at market prices once their economies are opened up and previous implicit subsidies due to overvalued exchange rates and non-payment of counterpart funds are removed (see Rekve and Torp, 1995, for further comments in this regard). Yet, this does not rule out a priori a potentially useful role for commodity support. The users of such aid can be given the necessary subsidy elements in a variety of different ways, if they were not contemplating to buy the goods on strictly commercial terms.

\section{[Table 3 about here]}

In line with the falling trend for CIS, other import assistance in the form of support to open general license (OGL) systems and credit lines grew from hardly anything in 1988 to $45 \%$ of Danish BOP in 1994. Credit lines consisting of foreign exchange transferred to Central Banks in the receiving countries have been used as a way of facilitating tying to purchases in Denmark. Thus, this modality has seen from the receiving countries point of view suffered from shortcomings similar to those of the CIS mechanism, and it has opened up considerable possibilities for corruption due to the sizeable economic rents involved. Limited knowledge in the receiving countries about Danish suppliers have, in addition, served as a constraint to making more effective use of the credit line modality.

Funds transferred in connection with OGL systems have so far mainly been disbursed as co- or parallel financing with the World Bank. Hence, foreign exchange has been supplied and sold to importers through different kinds of auctioning systems, increasing the import capacity of the country in question and financing in this way the import of goods contained in long positive lists or excluded by short negative lists. Danish OGL funds have normally been used to underpin the implementation of liberalization policies, and it follows that tying to purchases in donor countries is less feasible, since no implicit subsidy element is involved for the importer.

Nevertheless, the OGL modality can in weak institutional systems suffer from exactly the same problems as the CIS system, when it comes to non-payment of counterpart funds and potentially arbitrary ways of getting access (i.e., license) to the foreign currency provided. This can only be avoided if due care is taken in the design as well as in the implementation stage. Moreover, data on the OGL instrument are particularly difficult to interpret. Disbursed means in this context disbursed by Danida to World Bank accounts, but this does not imply that the funds involved have actually been released to the country in question. This is inter alia important, since it would appear that there are several instances where the World Bank has preferred to use own funds before releasing donor money, making the link between the disbursement figures and their actual use even more tenuous. 
It can, finally, be highlighted that transferring resources to poor countries in the form of foreign currency remains a relevant aid modality independent of the need for OGL mechanisms during a transition period where economic reforms are undertaken. Even if the currency of a given country is fully convertible and the foreign exchange market operates efficiently, domestic savings may still be insufficient to satisfy existing basic human needs and meet the investments required for future growth. In this case, foreign support (i.e., savings) amounts simply to a supplement to domestic savings and as such is equivalent to general budget aid, since there is, in other words, no difference, in principle, between financing selected components of the budget or providing a free allocation of foreign exchange.

Debt relief was an important component of Danish BOP during the period 1979-87 when an amount of almost DKK 2.2 billion of Danish state loans owed by some 15 least developed countries and a few low-income countries were cancelled in accordance with the UNCTADdeclaration of 11 March 1978 (Danida, various years). Yet, during the subsequent period in focus in this study, debt relief amounted to only $10 \%$ of total BOP, although it reached almost $30 \%$ in some years. SAP cofinancing is the last component of Danish BOP. This modality has been used since 1991 , and has on average accounted for $4.4 \%$ of total BOP. This share has, moreover, been relatively stable, in contrast to other policy related aid.

The evolution of total BOP from Danida and its importance in the overall aid programme, the distribution by major recipients and the composition by category are issues already discussed above. Yet, in relation to Danish BOP, a distinctive feature has also been the use of only one or two instruments in no less than five out of the eight main recipients. More specifically, the major recipient of Danish BOP, Bangladesh, received this aid exclusively as CIS (see Table 4). In addition, two-thirds of the BOP assistance to Bangladesh can as shown in Table 5 be classified as fertilizers. Fertilizer provided to Bangladesh was therefore equivalent to a remarkable $18 \%$ of total Danish BOP during the period 1988-94. The total share of Danish fertilizer supplied amounted to an equally impressive share of $23 \%$.

[Table 4 and 5 about here]

A number of the main recipients of Danish BOP, which received a substantial share of the BOP as CIS in the early years of the 1988-94 period, experienced a structural shift in the composition of the BOP from the early years of the 1990s. Tanzania received substantial amounts of CIS in the form of cement during the years 1988-91, amounting to $21 \%$ of total BOP to Tanzania during the period 1988-94. Yet, in 1991 Tanzania had DKK 90.5 billion of debt to the Danish Export Credit Council relieved in accordance with the socalled Toronto terms and parallel financing at limited scale with the World Bank was used as a modality in 1994.

Co-financing with the World Bank at a considerable scale in relative terms has only been used in Mozambique and Zambia; but parallel financing with the World Bank was used as a modality in Kenya (OGL/credit lines), Zimbabwe (OGL/credit lines), Uganda (debt relief and OGL/credit lines), Mozambique (OGL/credit lines), and Nicaragua (debt relief). It would for analytical purposes have been desirable to be able to distinguish here between OGL support, which is untied in nature and generally implemented in collaboration with the World Bank, and the credit lines, which have typically been tied to purchases in Denmark or developing countries. However, this has, as already mentioned, not been possible based on the information available. 
Disbursements to OGL systems and credit lines, listed under headings such as balance of payments support and structural adjustment in the brief project descriptions from StS.4, have been made under the same file numbers. To be able to distinguish in detail between OGL and credit line figures would therefore require a careful review of all the Danida Board documents on the basis of which this aid was approved. This would clearly be beyond the scope of this study, but it is known that common practice has been to approve OGL/credit line packages where 50\% would be used for untied OGL support and the remaining $50 \%$ for tied credit lines. This practice can, in other words, be seen as a way of balancing the twin needs of Danida for rapid disbursement and tying against each other. One would, however, be hard pressed to argue that this can be justified based on an analysis of the particular situation and developmental needs of the receiving country.

\section{Policy and Other Guidelines}

A review of existing Danida strategy and policy documents as well as annual reports and similar publications mentioned in the list of references reveals that there is no clearly defined set of policies related specifically to Danish BOP. A study on programme aid contains a variety of general considerations as to when and where the various BOP modalities may be more or less appropriate (Danida, 1994a, pp. 31-33). Yet, these considerations do not make up a policy as such. It would, moreover, on the basis of the documents and interviews undertaken in relation to this study appear that there are, indeed, no examples of Danish BOP having been used as policy based aid in the sense that explicit conditionalities were attached.

The lack of policy guidelines is particularly pronounced in relation to the CIS. The CIS has mainly been used as a means of quickly disbursing in a residual and tied manner any unspent aid funds at the end of the year due to lack of absorptive capacity in the receiving country as measured by the annual Danida aid allocation to the country in question (see also T\&B Consult, 1994). Whether such CIS aid would further or delay a process of economic reforms has evidently not been a matter of concern, and macroeconomic gap-based considerations certainly did not form part of the decision making process. Rather, the CIS modality has, in addition to being a rapid disbursement mechanism, been viewed as a useful way of increasing procurement in Denmark. This is put further into perspective by the fact that Danida has found it impossible to reach a level of disbursements through Danish suppliers equivalent to $50 \%$ of the aid budget, which was established in 1988 as a declaration of intent.

The structural shift in the composition of Danish BOP, which took place after 1991 could possibly be a signal that a more policy based approach was taken. However, it can safely be hypothesized that the shift was mainly caused by the collapse in the demand for Danish CIS as discussed above. Furthermore, while debt reduction, OGL/credit lines and co-financing modalities can certainly be used in an active and policy oriented manner, this does not appear to have been the case in general for Danish BOP. Thus, the change probably took place more by default than by design. This is underscored by the fact that debt relief has, according to Danida (1994a, p. 8), not so far been an integrated component of Danish programme aid in relation to the formulation of Danish views on conditionalities and policy issues. On the contrary, only rather vague references to the underlying set of assumptions and the general policy trend in negotiations in the Paris Club and similar fora can be identified. 
Consequently, while the Danida approach taken in the area of debt relief amounts to fully backing the policy line and conditionalities pursued by the World Bank and other multilateral agencies, this has been done in an implicit way, rather than reflecting clear policy choices. At the same time, Danida has in line with the increasing criticisms of the 'orthodox' approach to stabilization and structural adjustment tried to influence the World Bank through its Board of Governors and other available formal and informal channels. Whether such initiatives have been successful is left as an open question here; but it is a fact that recent concerns expressed by the World Bank are much more in line with traditional Danish aid priorities such as poverty alleviation and cross cutting themes related to gender, the environment etc. (see Danida, 1994a, for an elaboration of these points).

A more direct Danish involvement in the policy formulation process and the identification of explicit aid-conditionalities might have been possible in relation to OGL/credit lines and cofinancing with the World Bank. Nevertheless, it is also in this area difficult to identify a clear-cut and active link between the use of Danish BOP support and declared aid priorities. Existing studies (such as Danida, 1988; Danida, 1994a; and T\&B Consult, 1994) consistently recommend that Denmark should enter more directly into the policy dialogue and develop its capacity for independent assessments, taking as a starting point discussions with the World Bank, IMF, other bilateral donors and the recipient country. Finally, credit lines have in large measure also during recent years been tied to procurement in Denmark, which is in stark contrast to the liberalization policies pursued by structural adjustment.

In spite of the above, it can by way of conclusion be highlighted, first, that it has been a well defined Danish policy that tying should not, in principle, exclude goods produced in developing countries at competitive prices. The extent to which this policy has had any impact, in practice, is not, however, entirely clear. Secondly, counterpart funds generated through the sale of inputs to domestic producers, goods for final consumption as well as foreign exchange should according to Danish guidelines end up with either the Ministry of Finance or the Central Bank without strings attached.

Denmark has in the above way tried at the policy level to counter the distorting effects, which are inevitable if counterpart payments are not collected in a systematic and timely manner. Yet, the fact that this approach has not always been followed consistently in practice is well documented (see for example T\&B Consult, 1994, and Danida, 1994a). It has in this regard been speculated that Danish Embassies have focused too much on the need to disburse and consequently have not pursued the issue of payment of countervalues to the extent desirable. It is hard to gauge the exact extent to which this may be a correct interpretation. Nevertheless, despite the macro nature of BOP support, it is widely reported that the overall monitoring of macroeconomic developments is inadequate. There are, moreover, examples where Danish BOP support was not suspended even if the adjustment programme clearly went off track, and the World Bank stopped lending, leaving the underlying rationale for the lending and release of funds open to varying interpretations.

On the other hand, by striving at having as few strings attached to local currency generated as possible and avoiding undue additional demand pressure caused by the incomes generated by the supply of foreign goods, Danida has certainly attempted to strengthen the capacity of local government institutions to achieve macroeconomic balance. This is so even if it must be squarely recognized that the Danish amounts involved in general have been of a relatively limited scale. 


\section{Evaluation Studies}

The most comprehensive study of Danish BOP to date was completed in 1994 (T\&B Consult, 1994). It consists of a main report and five country case studies. The case studies of Bangladesh, Nicaragua, Tanzania, Mozambique and Uganda contain a brief description of the overall macroeconomic situation in the country concerned, including a listing of the most important ongoing economic and political changes, followed by a descriptive appraisal of the BOP provided. Finally, all studies discuss various dimensions of BOP as a policy related instrument. These evaluations touch upon a wide range of issues, and an attempt is made in what follows to characterize them in accordance with the guidelines provided by White (1995), before discussing briefly the other available studies in this field. For a tentative overview of how the studies can be classified, Table 6 can be consulted.

[Table 6 about here]

\section{I BOP to Bangladesh, Nicaragua, Tanzania, Mozambique and Uganda}

The case studies under this heading review the individual components of BOP separately, but except for co-financing with the World Bank, the analyses are focused on microeconomic and administrative issues. No quantified microeconomic cost-benefit analysis is conducted, although an attempt is made to clarify the kinds of commodities imported and assess in qualitative terms the relevance of the products supplied and their effect on capacity utilisation in the respective firms and sectors involved. It is, in particular, noted that there have been problems with collecting counterpart funds, and that this and other distortions have been the major reason for local companies demanding Danish products. There is, however, no quantified information available to assess the microeconomic dimensions of the counterpart issue in more concrete terms.

When it comes to administrative issues, the evaluation studies are in addition to detailed accounts of what actually was delivered, where and when, focused on the problems connected with the collection of counterpart funds. Other administrative shortcomings, like administrative difficulties with disbursements, transportation obstacles, problems with local governments etc., are evaluated in brief terms only, and some of the case studies have relatively little to say in these regards. Yet, all five studies put great emphasis on making concrete recommendations as to the way in which future BOP should be designed and disbursed.

As regards the macroeconomic effects of increased funds made available through BOP and the impact of modified policies, there are differences in the way in which co-financing with the World Bank in support of Structural Adjustment Programmes (SAP) is treated as compared to the other BOP instruments. The analysis of CIS funds is not carried out within a macroeconomic framework, and the possible effects on macroeconomic indicators (i.e., inflation, growth, public sector budgets etc.) are not pursued in detail, although some qualitative observations on possible macro effects of the goods supplied are made throughout the various reports. Also the question of tying and related problems are discussed at length. Nevertheless, while the fungibility issue is referred to in the main summary report, it is not taken up in the individual country studies and possible inflationary effects are left unaddressed. The CIS picture also manifests itself with regard to credit lines, debt relief and OGL, and the main argument put forward for not analysing the impact of these kinds of Danish BOP at the macroeconomic level is their relatively limited size 
in the overall picture.

On the other hand, in evaluating co-financing with the World Bank, descriptive macroeconomic reviews are included. The methodology adopted is before-versus-after, and the analyses are limited to listings of policy changes and variations in important macroeconomic variables based on various World Bank reports and similar sources of information. Thus, little can, in fact, be deduced about the actual impact of policy reforms and the macro funds made available. It follows that no attempt is made to carry out independent macroeconomic modelling or quantified analyses of the underlying behavioural relationships in the respective countries. Finally, it is repeated that it is impossible to isolate the macroeconomic effects of Danish BOP.

\subsection{Other BOP Studies}

The above studies were as noted focused on microeconomic and administrative topics. The same accounts for the studies by CASA (1989), Cooksey (1987), and Danida (1988) covering BOP activities in Tanzania and Mozambique such as the supply of industrial tallow for bar soap production. None of these studies address macro issues in detail although questions related to tying are touched upon in addition to general comments about the usefulness of commodity assistance as a tool in support of economic recovery policies. Instead these three evaluations emphasize a series of delivery and technical production problems, the quality of the supplies and the effect on capacity utilization in addition to addressing issues related to the payment of counterpart funds etc.

The last group of studies to be commented on include a series of internal reviews carried out in some of the Danida programme countries under the leadership of Danida staff. These studies are not published, and the following is therefore limited to some remarks about their general content and the methodology applied. By way of introduction these reviews normally include a brief macroeconomic survey of the country in question based on a critical reading of available statistics and short visits to the country concerned. Brief accounts of the economic reform process (including as well the functioning of foreign exchange auctioning systems) may also be included in addition to statements about existing savings- and foreign exchange gaps. Yet, no independent formal analyses or data collection take place at the macro level. The issue of fungibility is seldom addressed in a coherent manner, and linkages with economic and social indicators of development and the impact of BOP are discussed in qualitative terms only.

Hence, also the internal Danida reviews normally put considerable emphasis on microeconomic issues in addition to addressing administrative procedures and topics related to effective programme management. Consequently, existing procedures and their adequacy, disbursements rates, the access of importers to foreign currency and potential economic rents and distortions, the auditing of payments of counterpart funds and problems created by complex tying rules are normally discussed at great length. Moreover, while comments may be made on capacity utilization, explicit cost-benefit analysis hereof is not undertaken. Recommendations are often made on the composition of future BOP and the procedures to be followed, but these suggestions are usually kept in rather broad and generalized terms. However, this should come as no surprise. The internal Danida reviews have been carried out under great time pressure as quick desk studies combined with short country visits leaving very limited possibility for more in-depth and quantified analysis. Finally, these reviews do not, in fact, have the status of being evaluations. 


\section{Conclusion}

Danish BOP has been relatively small as compared to BOP from other likeminded donors, and Commodity Import Support (CIS) has by far been the most important modality used. Danish CIS cannot in general be characterized as policy based aid, and gap-based considerations did not form an identifiable part of decision making matrices. CIS was, instead, largely demand driven in the sense that commodities were made available to local importers, who derived substantial economic rents due inter alia to exchange rate overvaluation and incomplete collection of counterpart funds. At the same time, CIS was useful to Danida as a means of quickly disbursing in a residual manner unspent project balances building up due to delivery constraints caused by faltering absorptive capacity.

This study also reveals that a major structural change is underway in Danish BOP. Other BOP modalities such as OGL support, credit lines and cofinancing with the World Bank are on the rise. Nevertheless, the extent to which this lending can be termed policy based is questionable. On the contrary, it would appear that active Danida involvement in the policy dialogue and in the establishment of policy conditionalities has been, at best, rather limited. Monitoring of macroeconomic issues and independent analyses is inadequate, and BOP disbursements have continued to reflect the need to spend funds in a residual manner, while at the same time increasing the share allocated to procurement in Denmark. Similarly, no initiatives have apparently been taken together with other donors to ensure greater continuity in BOP disbursements, which have fluctuated widely from one year to the next with no reference to the needs of receiving countries.

Finally, existing evaluations and reviews are mainly focused on micro- and administrative topics with only very scarce analysis of the intricate issues linked to the macroeconomic effects of BOP funds and adjustment policies. Reflections about macro impact are limited to comparing beforeand-after situations combined with cursory review of mainly World Bank data and studies. In sum, very little is, indeed, known about the overall impact of Danish BOP. It can therefore safely be concluded that this area of economic enquiry is certainly ripe for further research both in relation to the need for well defined evaluation techniques and in the form of comparative country case analysis of BOP experiences. This is so, in particular, given the commitment stated in a variety of Danida documents to develop independent assessments of the ongoing reforms in some of the major Danida programme countries. 


\section{References}

Bhaduri, Amid et al., (1993): 'Evaluation of Macroeconomic Impacts of Imports Support to Tanzania'. Trondheim: UNIT, University of Trondheim.

CASA (1989): 'Danish Supplies of Industrial Tallow for Production of Bar Soap in Mozambique'. Copenhagen: Danida.

Cassen, Robert (1994): Does Aid Work?, 2nd ed. Oxford: Clarendon Press.

Cooksey (1987): 'Danish Assistance to the Tanzanian Soap Industry'. Copenhagen: Danida.

DAC (1991): Principles of Programme Aid. Paris: OECD.

Danida (1985): 'Tanzania: Danish Commodity Aid', Part I-V. Copenhagen.

Danida (1988a): 'Tanzania - Commodity Assistance'. Copenhagen.

Danida (1988b): Strategisk Planlagning - Handlingsplan. Copenhagen: Ministry of Foreign Affairs.

Danida (1994a): 'Programbistand - Rapport fra Arbejdsgruppen'. S.1, J.nr. 104.Dan.4/59.g. Copenhagen: Ministry of Foreign Affairs.

Danida (1994b): En Verden i Udvikling - Strategi for Dansk Udviklingspolitik Frem Mod Ar 2000. Copenhagen: Ministry of Foreign Affairs.

Danida (various years): Danidas Arsberetning. Copenhagen: Ministry of Foreign Affairs.

Danida (various years): Danmarks Statslige Bistand til Udviklingslandene - Den Rullende 5 års Plan. Copenhagen: Ministry of Foreign Affairs.

Doryie, Josuhua et. al. (1993): Fungibility and Sustainability: Import Support Tanzania. SIDA Evaluation Report. Stockholm: SIDA.

Mosley, Paul et al. (1991): Aid and Power: The World Bank and Policy Based Lending. London \& New York: Routledge.

Rekve, Peter and Jens Erik Torp (1995): 'Danske Erfaringer med Makroøkonomisk Bistand'. Samfundsфkonomen, No. 4, pp. 39-46.

Riddell, Roger (1987): Foreign Aid Reconsidered. London: James Currey.

SIDA (1993): Principles of Import Support. Stockholm.

Skarstein, Rune et al. (1988): Norwegian Commodity Import Support to Tanzania. Evaluation report 4.88. Oslo: Norwegian Ministry of Foreign Affairs. 
T\&B Consult (1994): Evaluation of Danida's Balance of Payments Support, vol. I-III. Copenhagen: Danida.

White, Howard (1992): 'The Macroeconomic Impact of Development Aid: A Critical Survey'. The Journal of Developments Studies, Vol 28, No.2, pp. 163-240.

White, Howard (1992): 'What Do We Know About Aid's Macroeconomic Impact?'. Journal of International Development, Vol. 4, pp. 121-137.

White, Howard (ed.) (1994): The Macroeconomics of Aid: Case Studies of Four Countries. The Hague: ISS.

White, Howard (1995): 'Evaluation Methodology for Balance of Payments Support'. Background paper prepared for the workshop on the evaluation of balance of payments support, The Hague, 12-13 October, 1995.

White, Howard and Joke Luttik (1994): 'Country-wide Effects of Aid'. World Bank Policy Research Paper No. 1336. Washington, D.C.: World Bank. 

Table 1: Danish Balance of Payments Support 1988-1994

\begin{tabular}{|c|c|c|c|c|c|c|c|c|}
\hline & 1988 & 1989 & 1993 & 1991 & 1992 & 1993 & 1098 & 101.1 \\
\hline $\begin{array}{l}\text { Potal Damsis Balance of } \\
\text { Payments Support (asall. BKK) }\end{array}$ & 243.1 & 329.8 & 286.3 & 462.0 & 360.5 & 278.4 & 218.3 & 2178 \\
\hline $\begin{array}{l}\text { Danish BoP (share of total } \\
\text { Damish bilateral aid in } \% \text { ) }\end{array}$ & 9 & 10 & 8 & 12 & 9 & 6 & 5 & 8 \\
\hline 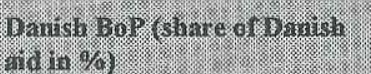 & 4 & 5 & 4 & 6 & 4 & 3 & 2 & 4 \\
\hline
\end{tabular}

Source: Danida StS.2

\section{Figure 1: Danish Balance of Payments Support 1988-1994}

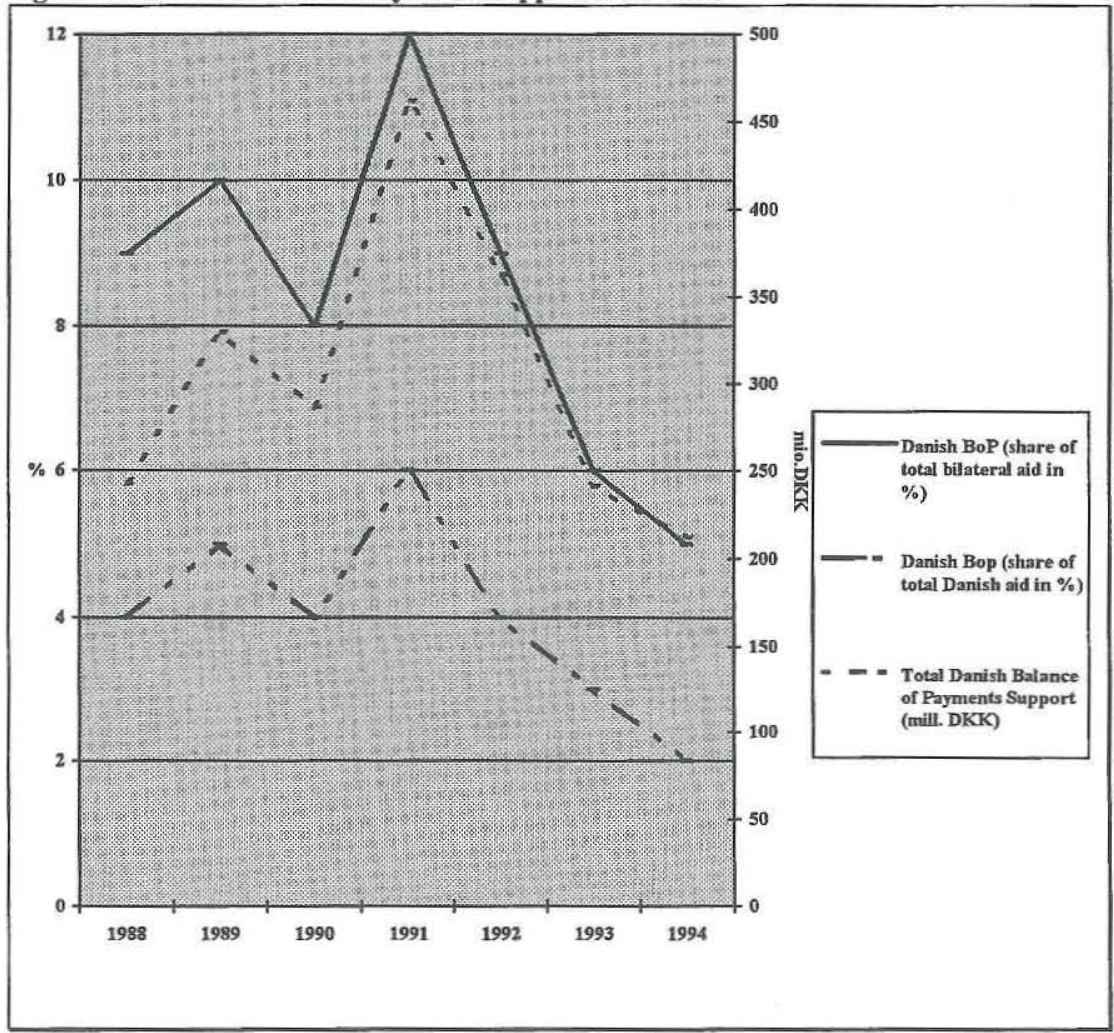

Source: Danida StS.2 
Table 2: Main recipients of Danish Balance of Payments Support 1988-1994, mill. DKK

\begin{tabular}{|c|c|c|c|c|c|c|c|c|c|}
\hline & 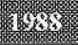 & 198 & 190 & (x) & 1952 & 1398 & $1,0.45$ & 6 & 28 \\
\hline 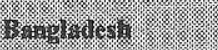 & 106.9 & 156.7 & 141.3 & 143.3 & 55.0 & -21.8 & 0.8 & 582.2 & 26.9 \\
\hline inin: & 2.4 & 30.4 & 17.5 & 30.8 & 17.4 & 4.2 & 0.5 & 103.2 & 4.8 \\
\hline Mirotinibizin: & 9.9 & 13.5 & 9.4 & 7.5 & 27.8 & 40.7 & 35.1 & 143.9 & 6.6 \\
\hline 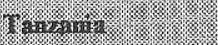 & 104.2 & 76.9 & 91.8 & 139.6 & 50.8 & 3.1 & 16.7 & 483.1 & 22.3 \\
\hline Hernidin & 12.5 & 10.0 & 5.7 & 35.6 & 40.6 & 71.9 & 8.6 & 184.9 & 8.5 \\
\hline 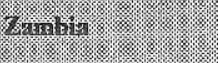 & 0.0 & 0.0 & 0.0 & 18.1 & 60.5 & 23.8 & 22.5 & 124.9 & 5.8 \\
\hline 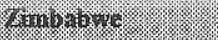 & 3.6 & 15.4 & 0.0 & 0.0 & 25.0 & 35.0 & 62.8 & 141.8 & 6.5 \\
\hline Micht 3 ; init & 0.0 & 12.0 & 15.3 & 38.4 & 0.60 & -0.4 & 0.0 & 65.7 & 3.0 \\
\hline 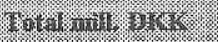 & 239.5 & 314.9 & 281.0 & 413.3 & 277.7 & 156.5 & 147.0 & 1829.7 & 84 \\
\hline 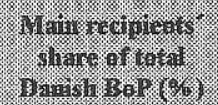 & 99 & 95 & 98 & 89 & 76 & 57 & 68 & 84 & \\
\hline
\end{tabular}

Source: Danida StS. 2

Note: Negative shares are due to insurance coverage of damaged goods 
Table 3: Main categories of Danish Balance of Payments Support, 1988-1994

\begin{tabular}{|c|c|c|c|c|c|c|c|c|}
\hline & 988 & 1989 & 1998 & 1091 & 1992 & 19993 & 1994 & grim \\
\hline CIS(n) (mill, 0Kk) & 230.6 & 299.8 & 270.6 & 301.9 & 242.3 & 108.2 & 82.9 & 1536.3 \\
\hline Share of total Bop in $\%$ & 94.9 & 90,9 & 94.5 & 65.3 & 67.2 & 38.9 & 38.0 & 70.5 \\
\hline Bebt relief (mill. BKM) & 0.0 & 0.0 & 1.7 & 134.2 & 20.2 & 52.2 & 21.5 & 229.8 \\
\hline Share of total BoP in \% & 0.0 & 0.0 & 0.6 & 29.0 & 5.6 & 18.8 & 9.8 & 10.5 \\
\hline $\begin{array}{l}\text { Sapport of credit lines and } \\
\text { OCtho) (mill, Diris) }\end{array}$ & 12.5 & 30.0 & 14.0 & 25.9 & 58.0 & 78.0 & 98.6 & 316.0 \\
\hline Share of total Bol ia \% & 5.1 & 9.1 & 4.9 & 5.7 & 16.1 & 28.0 & 45.2 & 14.5 \\
\hline 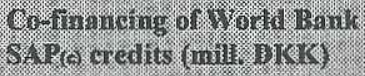 & 0.0 & 0.0 & 0.0 & 0.0 & 40.0 & 40.0 & 15.3 & 95.3 \\
\hline Share of total RoP in \% & 0.0 & 0.0 & 0.0 & 0.0 & 11.1 & 14.3 & 7.0 & 4.4 \\
\hline Total & 243.1 & 329.8 & 286.3 & 462.0 & 360.5 & 278.4 & 218.3 & 2178 \\
\hline
\end{tabular}

Source: Danida StS.2
(a) CIS - Commodity Import Support
(b) OGL - Open General Licence system
(c) SAP-Structural Adjustment Programme 
Table 4: Danish Balance of Payments Support by category and main recipients

\begin{tabular}{|c|c|c|c|c|}
\hline Countries & CIS & Debt relief & $\begin{array}{l}\text { OGi and credit } \\
\text { lines }\end{array}$ & $\begin{array}{l}\text { Co-fimancing of } \\
\text { World Bhak S I I } \\
\text { credins }\end{array}$ \\
\hline Bangladesh & 582.2 & 0.0 & 0.0 & 0.0 \\
\hline Renys: & 43.2 & 0.0 & 60.0 & 0.0 \\
\hline Moranihidue & 48.9 & 0.0 & 40.0 & 55.3 \\
\hline Tramsanan & 382.8 & 90.5 & 9.8 & 0.0 \\
\hline Ugand: & 66.9 & 34.6 & 83.4 & 0.0 \\
\hline Lambia & 84.9 & 0.0 & 0.0 & 40.0 \\
\hline Zimbabore & 19.0 & 0.0 & 122.8 & 0.0 \\
\hline Nicuragua & 31.9 & 33.8 & 0.0 & 0.0 \\
\hline Other: & 276.5 & 70.9 & 0.0 & 0.0 \\
\hline Total & 1536.3 & 229.8 & 316.0 & 95.3 \\
\hline
\end{tabular}

Source: Danida StS.2 
Table 5: Danish Commodity Import Support by category and main recipients

\begin{tabular}{|c|c|c|c|c|c|c|}
\hline $\begin{array}{l}\text { Commodily } \\
\text { Import Support }\end{array}$ & Fertilizers & Cement & $\begin{array}{l}\text { Spare } \\
\text { parts }\end{array}$ & $\begin{array}{l}\text { Tecnical } \\
\text { soap }\end{array}$ & $\begin{array}{l}\text { Unspecified } \\
\text { CIS (a) }\end{array}$ & Other (1S \\
\hline Bangladesh & 391.7 & 0.0 & 57.1 & 0.0 & 0.0 & 133.4 \\
\hline Keny: & 0.0 & 0.0 & 0.0 & 0.0 & 0.0 & 43.2 \\
\hline Mlorabni bigue & 0.0 & 0.0 & 0.0 & 25.1 & 12.5 & 11.3 \\
\hline Tanzania & 79.7 & 103.8 & 0.0 & 14.1 & 89.3 & 95.9 \\
\hline Uganda & 0.0 & 52.1 & 0.0 & 14.8 & 0.0 & 0.0 \\
\hline Zambian & 38.1 & 0.0 & 46.8 & 0.0 & 0.0 & 0.0 \\
\hline Timisabue & 0.0 & 0.0 & 0.0 & 0.0 & 0.0 & 19.0 \\
\hline Nicaragua & 0.0 & 0.0 & 2.4 & 0.0 & 0.0 & 29.5 \\
\hline Others & 0.0 & 0.0 & 0.0 & 0.0 & 0.0 & 276,6 \\
\hline Total & 509.5 & 155.9 & 106.3 & 54.0 & 101.8 & 608.8 \\
\hline
\end{tabular}

Source: Danida StS.2

(a) Unspecified Commodity Import Support usually indicates that the CIS consists of a wide group of different commodities and therefore these are not specified any further in the short programme description

(b) Other Commodity Import Support includes cables, medicine, road rollers, seeds etc. 
Table 6: Classification of Balance of Payment Support Evaluations

\begin{tabular}{|c|c|c|c|c|}
\hline Countries & Nifero & Vhicro & Macro funds & Adininistration \\
\hline Bangladesh (1994) (a) & $\mathrm{X}$ & & & $\mathrm{X}$ \\
\hline Nicriragua $(1994)$ & $\mathrm{X}$ & & & $\mathrm{X}$ \\
\hline SAP wikh World Bank & & $\mathrm{X}$ & & \\
\hline Tamzania $(1994)$ & $\mathbf{X}$ & & & $\mathrm{X}$ \\
\hline Ugandia $(1994)$ & $\mathrm{X}$ & & & $\mathrm{X}$ \\
\hline -SAP vith Werld Bank & & $\mathrm{X}$ & & \\
\hline Mrozambique (1994) : & $\mathrm{X}$ & & & $\mathbf{X}$ \\
\hline SAP with W erld Bank & & $\mathbf{X}$ & & \\
\hline Tanrania $(1988)$ & $\mathrm{X}$ & & & $\mathrm{X}$ \\
\hline Tanzania (1987): : : : & $\mathrm{X}$ & & & $\mathbf{X}$ \\
\hline Nitozambigae (1989) & $\mathrm{X}$ & & & $\mathrm{X}$ \\
\hline
\end{tabular}




\section{Discussion Papers from Institute of Economics, University of Copenhagen}

94-01 Peter Hjertholm: Developing Country Debt in the 1990s: Is the Crisis Over?

94-02 Svend Albæk \& Per Baltzer Overgaard: Uniqueness in Two-type Signalling Games: Finite Response Sets vs. Continuum Response Sets.

94-03 Hans Christian Kongsted: Constancy of Structural Long-Run Relations in a Cointegrated VAR Model of Export Pricing.

94-04 Svend Albæk \& Per Baltzer Overgaard: Signalling to Competing Retailers: Receiver Discretion and Adverse Selection.

94-05 Christian Schultz: Reputation for Honesty in Repeated Games with One Long Run Player.

94-06 Ebbe Hendon, Hans Jørgen Jacobsen og Birgitte Sloth: Fictitious Play in Extensive Form Games.

94-07 Karl Gunnar Persson: Integration and Deregulation of European Grain Markets, 1500-1900.

94-08 Henrik Lando: The Dual Class Share System and the Market for Corporate Control.

94-09 Torben Tranæs: Unemployment and Policy Neutrality under Competition.

94-10 Henrik Lando: Allocating Durable Goods Through a First-Come Rule or Through Individual Ownership.

94-11 Hans Jørgen Jacobsen \& Christian Schuitz: Optimal Labor Contracts May Exhibit Wage Fluctuations Due to Wage Discrimination.

94-12 Hans Jørgen Jacobsen: On the Foundations of Nash Equilibrium.

94-13 Niels Thygesen: A Critical Examination of Target Zones and Reflections on the EMS Experience.

94-14 Peter Birch Sørensen, Lars Haagen Pedersen \& Søren Bo Nielsen: Taxation, Pollution, Unemployment and Growth: Could there be a "Triple Dividend" from a Green Tax Reform?

94-15 Egbert Dierker \& Birgit Grodal: Profit Maximization Mitigates Competition.

94-16 William Perraudin \& Bent Sørensen: Modelling Exchange Rates in Continuous Time: Theory, Estimation and Option Pricing.

$* * *$

95-01 Christian Schultz: Wages and Employment in a Repeated Game with Revenue Fluctuations.

95-02 Claus Thustrup Hansen: Labour Unions, Capital Accumulation, and the Natural Rate of Unemployment.

95-03 Henrik Hansen \& Anders Warne: Common Trends Analysis of Danish Unemployment. 
95-04 Jan Gunnarsson: Economic Properties and Expectations. How the Process of Learning Develops by Selection.

95-05 Keith Blackburn \& Lill Hansen: Public Policy and Economic Growth in an Imperfectly Competitive World of Interdependent Economies.

95-06 Ebbe Hendon \& Torben Tranæs: Decentralized Trade in a Small Market: The Possibility of Resale.

95-07 Egbert Dierker \& Birgit Grodal: Profit Maximization, Relative Prices, and the Maximization of Shareholders' Real Wealth.

95-08 Ebbe Hendon, Hans Jørgen Jacobsen, and Birgitte Sloth: Adaptive Learning in Extensive Form Games and Sequential Equilibrium.

95-09 Ebbe Hendon, Hans Jørgen Jacobsen, Birgitte Sloth, and Torben Tranæs: NASH Equilibrium in Lower Probabilities.

95-10 Hans Keiding: Allocations Dynamically Implemented in Renegotiation Proof Equilibrium.

95-11 Eirik Schrøder Amundsen \& Trond Bjørndal: Optimal Exploitation of a Biomass Confronted with the Threat of Partial Extinction.

95-12 Karsten Albæk \& Bent E. Sørensen: Worker Flows and Job Flows in Danish Manufacturing, 1980-91.

95-13 Karsten Staehr: Indexation, Contract Length, and the Cost of Disinflation in Economies with Extreme Inflation.

95-14 Carsten Krabbe Nielsen: Rational Belief Structures and Rational Belief Equilibrium.

95-15 Peter Brixen \& Finn Tarp: A Simple Macroeconomic Framework for South Africa.

95-16 Finn Tarp \& Mads Váczy Kragh: Danish Balance of Payments Support. 



ISSN 0902-6452 